International Journal of Research in Education and Sustainable Development | ISSN: 2782-7666

Vol. 1, Issue 3 (March, 2021) | www.ijaar.org

Journal DOI: www.doi.org/10.46654/IJRESD

Article DOI: www.doi.org/10.46654/IJRESD.1329

\title{
DEMOGRAPHIC FACTORS RESPONSIBLE FOR UNDERACHIEVEMENT AMONG UNDERGRADUATE ENGINEERING STUDENTS IN SOUTH-SOUTH FEDERAL UNIVERSITIES
}

\author{
Syder, Emily Inuadume Daniel \\ Department of Educational Psychology, Guidance and Counselling, \\ University of Port Harcourt, Choba, Port Harcourt \\ inuadume@gmail.com \\ Prof. O. G. Kemjika \\ Department of Educational Psychology, Guidance and Counselling, \\ University of Port Harcourt, Choba, Port Harcourt \\ Dr. I. E. Ehibudu \\ Department of Educational Psychology, Guidance and Counselling, \\ University of Port Harcourt, Choba, Port Harcourt
}

\begin{abstract}
The study investigated the demographic factors responsible for Underachievement among Undergraduate Engineering students in South-South Federal Universities". Four research questions and corresponding null hypotheses guided this study. Ex-post facto research design was used. A population size of 1,155 students from year 2 to 4 was used and a sample size of 630 was drawn. Three instruments were used, they are; the Demographic Inventory (DI), General Engineering Mathematics Underachievement Test (GEMUT) and Standard Progressive Matrix (SPM). The reliability of these instruments was tested on 20 respondents using Cronbach alpha method of internal consistency. The reliability indexes are 0.60, and 0.55 respectively for General Engineering Mathematics Underachievement Test (GEMUT) and Standard Progressive Matrix (SPM). Research question 1 was answered with simple percentage, while research questions 2 \& 3 were answered with One-way ANOVA. The corresponding null hypothesis 1 was tested with Z-test and one-way ANOVA associated with regressions to test hypotheses 2 \& 3. Hypothesis 4 was tested with simple linear regressions. Findings show that federal institutions of study significantly influence underachievement, while gender and department of study do not relate to underachievement in South-South Federal Universities. Also, there was a significant relationship among the CGPA and general engineering mathematic test among engineering students. The researcher recommends that course advisers, counsellors and lecturer should identify these underachievers early and appropriate counselling measures given; also, the Federal Government has to provide and supervise Federal Institutions.
\end{abstract}

Keywords: Demographic factors, Underachievement, Undergraduate Engineering Students, South-South, Federal Universities 


\section{INTRODUCTION}

\section{Background to the Study}

Academic decadence, failure of graduates to get useful, and the expanding pace of assessment negligence in our tertiary establishments' call for consideration. Reason; underachievement among undergraduate engineering students in tertiary establishment is an academic issue which has become a thing of worry to instructors, course guides, advocates, clinicians and parents. The word underachievement was first established in 15th century, it signifies a backward diminishing in an able student's capability to procure certain aptitudes and abilities required for polished methodology. The word underachievement is considered in the detailing of instructive strategies and practice which is routinely utilized by countries, homes, religions, types, areas of tutoring, physiological, ethnic, social relations to mean low scholarly accomplishment. Underachievement goes past low scholarly accomplishment.

Hornby (2010) characterized scholarly underachievement as challenges students face to perform less well particularly in school work. Scholarly underachievement is estimated by the student's exhibition from evaluation scores that is truly a portrayal of an individual work propensity later on and educational desires. It includes how much students have certain particular social qualities identified with inspiration (Doughyuck, Lim, Seon, Hutchison, Mark and Hwang, 2014).

The word underachievement is characterized as the negative unforeseen result of training which is ordinarily estimated corresponding to what is accomplished during an instructional program through continuous assessment test, used in evaluating the psychological space where the student doesn't have any inadequacy in school settings. It is finished with the use of teacher-made test or government sanctioned test built in the free response type (essay) or the short answer (objective test). The main point is on the teacher-made test and mental capacity test, from which the underachievement scores of students were gotten and utilized.

The word underachievement means doing what is not exactly expected or fail to meet expectations in an institutionalized arrangement of test (Logsdon, 2019). He considers underachievement in Mathematics as when the student's presentation isn't at par with his/her contemporaries; rather he is failing courses. Wikipedia (2018) defined underachievement as doing not exactly as expected in school which is estimated from scores of insight test. McCoach and Siegle (2003) see underachievement as an error between potential execution or accomplishment. This infers underachievement isn't one-point perception of quantifiable performance, it is dynamic if proper attention is given to the underachievers.

Engineering Mathematics, is offered in year 2 and finishes in year 4 first semesters and estimation to make ideas, fabricate products, extricate crude materials and change them into completed merchandise. Engineers offer various administrations region of specialization. The mechanical specialist offers fixing of autos and machines, ecological designing of streets, scaffolds and houses, while the oil and gas engineers create raw petroleum and other crude materials extricate. The electrical and electronic specialists engage in wiring of houses and coordinating of flow in circuit. Chemical Engineers produce synthetic substances and bombs. Other developing fields are Computer Engineering, Agricultural Engineering, and Mechatronics 
Engineering. Building a house requires high pace of aptitude in engineering, else they will expose the entire society to danger at workplace. If undergraduates have not accomplished well as students, they will uncover themselves, managers and society to high risk that could prompt extreme wounds. Most entrenched firms or companies employ outside specialists much grounded with the essential duties in completing their Engineering functions. Engineering Mathematics resembles any ordinary Mathematics, however somewhat specialized.

Engineering mathematics enables the engineers to produce equations, obey standards, and hypotheses which guide the Engineering practice. Each branch in Engineering is guided by standards and laws controlling the Engineering practices. Those in mechanical, electrical, compound, PC, mechatronics, oil and gas Engineering apply various laws and the primary guideline which help them in doing their obligations. Take for instance, when the country is having a census and during the production of drugs (the Chemical Engineers measure the right proportion and necessary materials needed, so as to control the level of harm the drug may cause to its consumers). Engineering Mathematics gives the student engineers an ability to think in abstract and logical terms, which is liken to be referred to as artificial intelligence, which is a condition that enables them to think in diverse ways. The Mechanical Engineers are in charge of the production and repairs of machine parts. In building a house, almost all the fields of engineering are fully involved in one stage or the other.

The Engineering principle that states that the prototype of the structure should be used first, so that they will know the number of things they need to put in the house and facilities required alongside the cost of building the house. Structural Engineers perform the duty of taking a sample of the work, map out the duration and the cost of the building so as to avoid wastages. The Electrical Engineers perform the role of wiring the house and fixing of sockets, bulbs and electrical appliances. The Petroleum and Gas Engineers are in charge of the extraction of raw materials and converting it into finished goods.

Engineering Mathematics offers the engineering students with different steps to take so as to arrive at the right solution. The principle of integration and differentiation helps to widen the knowledge of the trainee engineers. The principle of integration involves the combination of two things so that they work together effectively. On the other hand, the principle of differentiation states that when carrying out an engineering function, the Engineer must recognise the differences between two things. Furthermore, Engineering Mathematics aids the Engineering student to generate formulas from the scratch, using the binomial and paschal theorem. Binomial theorem is a mathematical expression that has two parts connected by the sign $\left(_{+}\right)$or the sign (-).

Past specialists see underachievement from two viewpoints; one as a differential accomplishment or low accomplishment, besides as a mental task, it builds the error between the person's exhibition on mental capacity in resulting school assessment (Smith, 2003). When there exists an error between a student's exhibition, underachievement has happened.

Variables like gender, federal institutions of study and departments of study were investigated. Ebenuwa-Okoh (2006) defines gender as socially constructive role value expectations for female and distinct from male. In academic studies, the responsibility of being a male or female in the school within any institutions are realities that are currently in the consciousness of everyone. According to Amao-Kehinde (2006), in our societies, gender 
stratification system tends to favour male in some degrees. It is believed that women power is minimal and confined to the household; hence they have less interest in academic exercises, but the reverse is the case with the female engineering students. On the other hand, in egalitarian social systems women have important role in institution sphere. Despite this today, women are crying out loud for equal academic opportunities as their male counterpart. The relationship between male and female has traditionally been one of unequal power, with man in a dominant position over women. Men may originally have become powerful in pre-industrial times because of their size, physical strength, freedom from child bearing duties allowed them to dominate women.

This pattern is breaking up because of the changing roles of women in contemporary society with the aid of peace education (Akpan - ita, 2008). Women who are very intelligent find it difficult to give up their academic, so they work very hard to avoid any form of carry over(s). They quest for equality with men in the area of career which is a conflict between the traditional roles of being a mother, wife and home keeper as well as modern roles of a career woman.

The department of study could also be a causative factor of underachievement. In Engineering faculty there are several departments representing their areas of specialization. These departments include; mechanical, electrical and electronics, chemical, petroleum and gas, computer, structural, production, agriculture and food engineering. These departments are made up of students, lecturers as well as the curriculum.

Federal institutions in Nigeria do not have a uniform standard for grading their students. Every institution has devised a best method for calculating student's Cumulative Grade Point Average (CGPA) for reasons best known to them. In most universities, the five-point CGPA grading system is adopted with a slight difference in the grades and method of computation. In time past, there are a lot of arguments on variations in our grading system, which led to the abolition of the pass degree with effect from 2013/2014 academic session by the National Universities Commission (NUC). This implies that the minimum pass mark for courses in the universities is $45 \%$ (grade $\mathrm{D}$ which is 2 points) instead of $40 \%$ which was a grade $\mathrm{E}$ with 1 point. It also implies that third class is the minimum class degree.

Okojie (2010) carried out an investigation on some of the Nigerian universities and noted that there is no uniformity in the standard of grading in our Nigerian universities. He identified some universities where they have $\mathrm{A}, \mathrm{B}+, \mathrm{C}+, \mathrm{D}, \mathrm{E}$ and $\mathrm{F}$ with grading points $5,4,3,2,1$ and 0 respectively. In order to reduce the rigidity of the grading system, the Student Records Management System (SRMS) was established by flexiSAF. This system was able to control the different methods of grading and computation of CGPA. SRMS was configured to use the old format for the returning students, and new format for the direct entry students so as to strike a balance between the former and newly implemented programme. It is based on this premise that this study therefore is to ascertain the Demographic factors responsible for underachievement among Undergraduate Engineering Students in South-South Federal Universities.

\section{Statement of the Problem}

Engineers are being judged by the work they perform. If the work they perform does not meet up the required standards, they will lose their clients, bonuses, promotions and in worst cases, they may get sacked. If an underachiever is employed in the labour market, he/she exposes their life, 
lives of their consumers and the society at large to high risk of loss of lives and properties, which in turn reduces the economic productivity. Underachievement later transforms to the occupational sector of the nation's economy, thereby leading to low level of productivity. The opinion of the public concerning the standard of education in Nigeria has become obvious following the release of the convocation brochure, which has always revealed students especially in the faculty of engineering, who graduate with first class, second class upper and lower degrees, but could not meet up with the required standards in the labour market. These students' achievements do not concur with the expectations of the university, government and investments of parents.

Those of them, who manage to continue, end up graduating with very poor CGPA that cannot earn them a well-paid job, or further their studies to improve their grades. In worst cases, after spending the required extra years, some are unable to graduate with a certificate. It is based on these reasons that the researcher wishes to investigate the Demographic factors responsible for underachievement among Undergraduate Engineering Students in South-South Federal Universities.

\section{Aim and Objectives of the Study}

The aim of this study is to determine the Demographic factors responsible for underachievement among Undergraduate Engineering Students in South-South Federal Universities. The following objectives guided this study, to:

1. determine the influence of gender (female/male) and underachievement among Undergraduate Engineering Students in South-South Federal Universities.

2. investigate the influence of federal institutions of study (UPH, FUO, UNIUYO, UNICAL \& UNIBEN) and underachievement among Undergraduate Engineering Students in SouthSouth Federal Universities.

3. examine the influence of departments of study and underachievement among Undergraduate Engineering Students in South-South Federal Universities.

4. find out if the CGPA and engineering mathematics is a true representation of underachievement among undergraduate students in south-south federal universities.

\section{Research Questions}

Three research questions were raised and guided this study:

1. how does Gender (female/male) influence Underachievement among Undergraduate Engineering students in South-South Federal Universities?

2. what is the influence federal institutions of study (UPH, FUO, UNIUYO, UNICAL \& UNIBEN) and Underachievement among Undergraduate Engineering students in South-South Federal Universities?

3. how do Departments of study influence Underachievement among Undergraduate Engineering students in South-South Federal Universities?

4. what is the joint relationship among students CGPA, Engineering mathematics and students' underachievement among undergraduate engineering students in South-south federal universities? 


\section{Hypotheses}

The following null hypotheses were tested at 0.05 level of significance.

1. There is no significant influence between gender (female/male) and underachievement among Undergraduate Engineering Students in South-South Federal Universities.

2. There is no significant influence between federal institutions of study (UPH, FUO, UNIUYO, UNICAL \& UNIBEN) and underachievement among Undergraduate Engineering Students in South-South Federal Universities.

3. Departments of study do not significantly influence underachievement among Undergraduate Engineering Students in South-South Federal Universities.

4. There is no significant joint relationship among students CGPA, Engineering mathematics and students' underachievement among undergraduate engineering students in South-south federal universities.

\section{Methodology}

The research design was Expo-facto. Expo-facto design was defined by Nwankwo (2013) as a type of design which involves collecting and analysing data about some variables which are already in place without manipulating any of them, in order to find out how some of them influence or are related to other variables. The researcher used this design to check the significant influence among gender, institutions of study and department of study, and joint influence of CGPA, Engineering mathematics underachievement test and underachievement of undergraduate engineering students.

\section{Population of the Study}

The target population of the study was all engineering students in 5 selected federal Universities in south-south geopolitical zone of Nigeria. As at the time of the study, there are 1,155 students from year 2 to 4 . Source: (Those that took part in the exercise/those that properly filled all the instruments in the selected federal Institutions).

\section{Sample and Sampling Techniques}

The sample size of the study was 630 underachieving engineering students from year 2 to year 4 whose scores in the SPM and GEMUT met the required cut-off point. That is those who scored above 45 which is the required cut-off point in the SPM and those who scored below 17 items out of the 25 items in the GEMUT. The multi stage sampling techniques were used. Firstly, the simple random sampling technique was used to select 10 departments in the faculty of engineering. Thereafter, the clustered sampling technique was used to share respondents based on their class level. Lastly, the stratified sampling technique was used to gather the respondents based on their gender.

\section{Instruments for Data Collection}

Four instruments were used for data collection; they are the Demographic Inventory (DI) consisting of institution of study, department of study, and gender, used to elicit personal information from the respondents. The General Engineering Mathematics Underachievement Test (GEMUT) which is used alongside with the Standard Progressive Matrix (SPM) to measure underachievement in engineering mathematics. 
The General Engineering Mathematics Underachievement Test (GEMUT) is researchers made. Items were drawn from Stroud and Dexter engineering mathematics text book. These items were drawn and modified by the researchers to measure respondents' calculative ability, speed and manual dexterity in answering questions. The questions were set in objective form and respondents were told to circle the right answer. It consisted of 25 items in options A to D form, in which there is a key and three distracters. All items were made compulsory to attempt. Each item carries 4 points, with a maximum score of 100 marks and a cut-off score of 50 marks. Students are expected to answer the questions in one hour.

Standard Progressive Matrix (SPM) is an instrument adopted from the work of Raven (1958) to measure the mental ability level of learners above age 5. It is used to measure intelligence quotient in pictorial form. It has a cut off score of 45 out of 60. Any score below 45 indicates some levels of underachievement. Students were asked to answer the questions in 45 minutes.

The total items on the questionnaires are eighty-five (85). Respondents are requested to rank them according to the extent to which they agree/disagree by ticking $(\sqrt{ })$ and circling where applicable.

\section{Validity of the Instruments}

The face validity of the instruments was determined through expert judgment. Some copies of the preliminary versions of the instruments were given to one expert in Measurement and Evaluation in the Department of Educational Psychology, Guidance and Counselling University of Port Harcourt for proper scrutiny and four experts in the Faculty of Engineering. Some modifications were made on the scales to ascertaining its suitability of items to the respondents, their suggestions and corrections were reflected in the final version of the work. Corrections in terms of the writing style, spacing and solving of the instruments.

\section{Reliability of the Instruments}

The instruments were tested on 20 respondents using the Cronbach alpha method of internal consistency. These 20 students who scored above (45) in the SPM and low in GEMUT that is those who scored below $68 \%$. Cronbach alpha was used to establish the reliability of the General Engineering Mathematics Underachievement Test (GEMUT) and it has a reliability value of 0.60. And the Standard Progressive Matrix (SPM) was established using Cronbach alpha method and it had a reliability value of 0.55 . This indicated that the items in the scales have internal consistency.

\section{Method of Data Collection}

The General Engineering Mathematics Underachievement Test (GEMUT) and Standard Progressive Matrix (SPM) scores were gotten from the respondents to form the underachievement scores for the study. The instruments were administered on the respondents through direct delivery method. Personnel used in collection of data were not uniform in all the tertiary Institutions. In UPH and FUO 2 Engineering lecturers, and 3 course representatives were used. In UNICAL, 3 Engineering lecturers and 1 course representative and one assistant course representative. In UNIBEN, and UNIUYO 4 Engineering lecturers and 1 student. These 
personnel were trained as facilitators to guide and supervise the process of filling the questionnaires. Collection of filled copies of the questionnaires was done at the spot in 3 hours.

\section{Methods of Data Analyses}

Analyses of data were done on the research questions and corresponding null hypotheses. Research question 1 was answered using simple percentage; while research questions $2 \& 3$ were answered using One-way ANOVA. On the other hand, ANOVA associated with z-test was used to test hypothesis 1; while hypotheses $2 \& 3$ were tested using one-way ANOVA associated with regressions. Lastly, hypothesis 4 was tested with simple linear regressions.

\section{Data Presentation and results}

Research Question One: How does Gender (female/male) influence Underachievement among Undergraduate Engineering students in South-South Federal Universities?

Table 4.1: simple percentage showing how gender influences underachievement

Gender $\mathrm{N}$ zcal. zcrit. df \%

Female $\quad 116$

Underachievement

$.290 \quad 1.96 \quad 628$
Male
514
81.59

To answer the research question as to how gender influences underachievement. 116 female underachievers ticked the questionnaire, while 514 male underachievers ticked the instruments. A simple percentage was used to measure how gender influences underachievement, and it shows that more males underachieve more by scoring $81.59 \%$ while females scored $18.41 \%$. Furthermore, a calculated z-value of .290 was obtained which is lower than the critical z-value of 1.96 which indicates that gender has no influence with underachievement, although males underachieve more than their female counterparts.

Hypothesis One: There is no significant influence of gender (female/male) and underachievement among Undergraduate Engineering Students in South-South Federal Universities.

Table 4.1.2: Independent samples z-test showing the influence of gender and underachievement

$\begin{array}{cccccccr}\text { Gender } & \mathrm{N} & \text { tcal. } & \text { tcrit. } & \text { df } & \text { F } & \text { Sig. } & \text { Decision } \\ \text { Female } & 116 & & & & & & \\ & & .290 & 1.96 & 628 & .006 & .766\end{array}$

Accept

Underachievement

Male $\quad 514$

In table 4.1.2, when these scores were subjected to independent samples t-test, it was found that the calculated t-value .290 obtained was not significant at .766, which is higher than the chosen .05 level of probability. Furthermore, a t-test analysis testing of the significance of 
this value showed that an F-value of .006 was gotten at 628 degree of freedom which yielded an associated p-value of .766. Hence, the null hypothesis of no significant difference is accepted. This means that gender has no significant influence of underachievement.

Research Question Two: What is the influence of federal institutions of study (UPH, FUO, UNIUYO, UNICAL \& UNIBEN) and Underachievement among Undergraduate Engineering students in South-South Federal Universities?

Table 2.1: Simple percentage showing the influence of federal institutions on underachievement

\begin{tabular}{|lrl|}
\hline Model & N & $\%$ \\
\hline UPH & 127 & 32 \\
FUO & 190 & 30 \\
UNIUYO & 67 & 11 \\
UNICAL & 103 & 16 \\
UNIBEN & 143 & 23 \\
Total & 630 & \\
Underachievement & & \\
\hline
\end{tabular}

To answer research question two, simple percentage was used, to show the influence of federal institutions of study and underachievement in South-South federal universities. University of Port Harcourt had (32\%) with 127 underachievers, Federal University Otueke (30\%) with 190 underachievers, University of Uyo (11\%) with 67 underachievers, University of Calabar (16\%) with 103 underachievers, and University of Benin (23\%) with 143 underachievers.

Hypothesis Two: There is no significant influence of federal institutions of study (UPH, FUO, UNIUYO, UNICAL \& UNIBEN) and underachievement among Undergraduate Engineering Students in South-South Federal Universities.

\begin{tabular}{|ll|l|l|l|l|}
\hline Model & N & $\begin{array}{l}\text { Sum of } \\
\text { Squares }\end{array}$ & Df & $\begin{array}{l}\text { Mean } \\
\text { Square }\end{array}$ & F \\
\hline UPH & 127 & & & & \\
FUO & 190 & & & & \\
UNIUYO & 67 & & & & \\
UNICAL & 103 & & & & \\
UNIBEN & 143 & & & & \\
Total & & & & \\
Underachievement & & & & & \\
\hline Between groups & & 3862.944 & 4 & 965.736 & 24.110 \\
& 2090.915 & 11 & 2090.915 & .000 \\
& 2338.683 & 1 & 2338.683 & .000 \\
& 1524.261 & 1 & 508.087 & .001 \\
\hline
\end{tabular}


From the result displayed in Table 4.2, it can be seen that when one way-ANOVA was used to analyze the data on federal institutions of study and underachievement, the Mean Squares of 965.736, 2090.915, 2338.683 for between groups and 508.087 for within groups. The result is that there is a significant relationship between federal institutions of study and underachievement. Furthermore, since the F values (11.136, 24.110 and 26.967 for between groups and 5.859 for within groups) is greater than the critical $t$ (1.96) at df of 4, 1, 1, and 3 for between groups and 625 for within groups at .001 level of significance for a one-tailed test, the null hypothesis is rejected. The result is that there is a significant influence of federal institutions of study (UPH, FUO, UNIUYO, UNICAL \& UNIBEN) and underachievement among Undergraduate Engineering Students in South-South Federal Universities.

Research Question Three: How do Departments of study influence Underachievement among Undergraduate Engineering students in South-South Federal Universities?

Table 4.3: Simple Percentage showing the influence of departments of study and underachievement

\begin{tabular}{|llll|}
\hline & Model & N & \% \\
\hline & CHM & 127 & 20 \\
MEC & 156 & 25 \\
& PGE & 105 & 17 \\
EEE & 86 & 14 \\
& CEE & 66 & 10 \\
& COM & 30 & 5 \\
& MCE & 21 & 3 \\
& AGE & 18 & 3 \\
& FOE & 6 & 0.95 \\
Total & CPE & 15 & 4 \\
Underachievement & & \\
\hline \multicolumn{6}{l}{} & & \\
\hline
\end{tabular}

Chemical Engineering has 127 underachievers with \%; Mechanical Engineering has 156 underachievers with 25\%, Petroleum and Gas Engineering has 105 underachievers with 17\%, Electrical and Electronics has 86 underachievers with 14\%, Computer Engineering has 66 underachievers with 10\%, COM has 30 underachievers with 5\%, MCE has 21 underachievers with $3 \%$, AGE has 18 underachievers with $3 \%$, FOE has 6 underachievers with $0.95 \%$, CPE has 15 underachievers with $4 \%$.

Hypothesis Three: Departments of study do not significantly influence underachievement among Undergraduate Engineering Students in South-South Federal Universities. 
Journal DOI: www.doi.org/10.46654/IJRESD

Article DOI: www.doi.org/10.46654/IJRESD.1329

Table 4.3: One-way ANOVA influence of departments of study and underachievement

\begin{tabular}{|c|c|c|c|c|c|c|}
\hline Model & $\mathrm{N}$ & $\begin{array}{r}\text { Sum of } \\
\text { Squares }\end{array}$ & df & $\begin{array}{l}\text { Mean } \\
\text { Square }\end{array}$ & $\mathrm{F}$ & Sig. \\
\hline $\begin{array}{ll} & \text { CHM } \\
& \text { MEC } \\
& \text { PGE } \\
& \text { EEE } \\
& \text { CEE } \\
& \text { COM } \\
& \text { MCE } \\
& \text { AGE } \\
& \text { FOE } \\
& \text { CPE } \\
& 630 \\
\text { Total } & \end{array}$ & $\begin{array}{c}127 \\
156 \\
105 \\
86 \\
66 \\
30 \\
21 \\
18 \\
6 \\
15\end{array}$ & & & & & \\
\hline \multicolumn{2}{|l|}{ Between groups } & $\begin{array}{l}771.661 \\
127.846 \\
14.170 \\
757.491\end{array}$ & $\begin{array}{l}9 \\
1 \\
1 \\
8\end{array}$ & $\begin{array}{l}85.740 \\
127.846\end{array}$ & \multirow[t]{2}{*}{$\begin{array}{l}.928 \\
1.383 \\
.153 \\
1.025\end{array}$} & \multirow[t]{2}{*}{$\begin{array}{l}.500 \\
.240 \\
.695 \\
.416\end{array}$} \\
\hline $\begin{array}{l}\text { Within groups } \\
\text { Total }\end{array}$ & & $\begin{array}{l}57292.713 \\
58064.375\end{array}$ & $\begin{array}{l}620 \\
629\end{array}$ & $\begin{array}{l}14.170 \\
94.686 \\
92.408\end{array}$ & & \\
\hline
\end{tabular}

According to the result displayed in table 4.3, a one way-ANOVA was used to analyse the data on departments of study and underachievement, the Mean Squares of 85.740, 127.846, 14.170 and 94.686 for between groups and 92.408 for within groups. The result is that there is no significant relationship between departments of study and underachievement. Furthermore, since the $F$ values (.928, 1.383 and .153 for between groups and 1.025 for within groups) is lesser than the critical $\mathrm{t}(1.96)$ at $\mathrm{df}$ of $9,1,1$, and 8 for between groups and 620 for within groups at .416 level of significance for a one-tailed test, the null hypothesis is accepted. The result is that there is no significant influence of departments of study and underachievement among Undergraduate Engineering Students in South-South Federal Universities.

Research Question Four: what is the joint relationship among students CGPA, Engineering mathematics and students' underachievement among undergraduate engineering students in South-south federal universities?

Hypothesis Four: There is no significant relationship between students CGPA and Engineering mathematics underachievement test among undergraduate engineering students in South-south federal universities. 


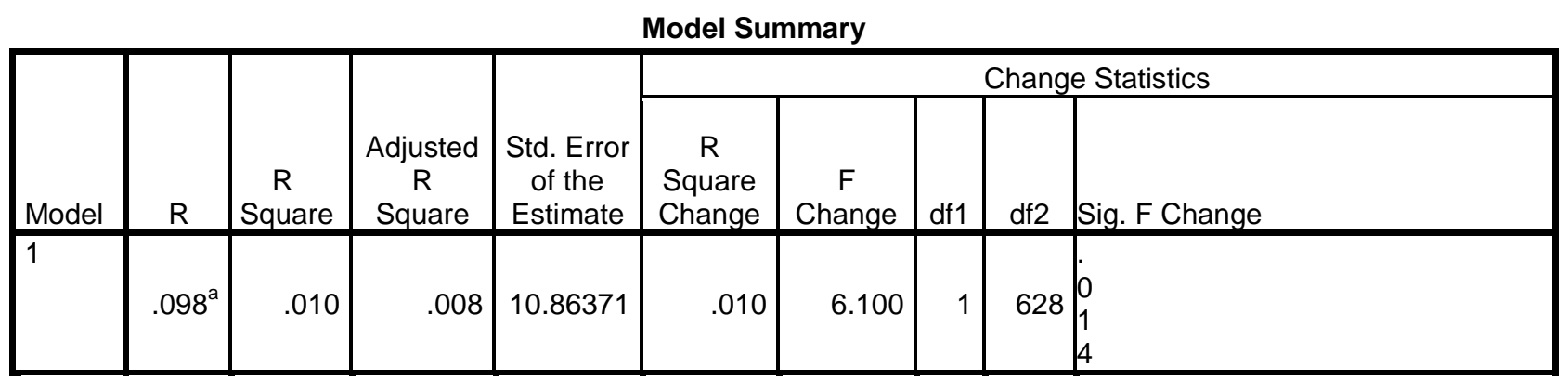

a. Predictors: (Constant), CGPA

Table 4.1: simple linear regression showing the relationship between the students CGPA and Engineering mathematics underachievement test

The Analysis of research question four showed that when scores on CGPA were correlated with underachievement using simple linear regression, an R-value of $.098^{\mathrm{a}}$ was obtained, an $\mathrm{R}^{2}$ of .010 and adjusted $\mathrm{R}^{2}$ of .008 were also gotten. From this result, it can be deduced that CGPA independently accounted for $0.05 \%$ of the variation in underachievement among Undergraduate Engineering Students in South-South Federal Universities. Furthermore, an ANOVA analysis testing the significance of this value showed that an F-value of 6.100 was gotten at 1 and 628 degrees of freedom which yielded an associated p-value of 6.100. Since the p-value obtained was lesser than 0.05, it therefore indicates that CGPA has a significant independent relationship with underachievement among Undergraduate Engineering Students in South-South Federal Universities. The null hypothesis was therefore rejected.

\section{Summary of major Findings}

After the collection and analysis of data, the following were the major findings:

- Gender does not have a significant relationship with underachievement among Undergraduate Engineering students in South-South Federal Universities.

- Federal institutions of study have a significant relationship with underachievement among Undergraduate Engineering students in South-South Federal Universities.

- Departments of study do not have a significant relationship with underachievement among Undergraduate Engineering students in South-South Federal Universities.

- There was a significant relationship among the CGPA, general engineering mathematic test and underachievement among engineering students.

\section{Discussion of Findings}

\section{Gender and Underachievement}

From the findings of this study, Gender does not have a significant relationship with underachievement among Undergraduate Engineering students in South-South Federal Universities. This result is surprising to the researcher because, she has always thought the 
Journal DOI: www.doi.org/10.46654/IJRESD

Article DOI: www.doi.org/10.46654/IJRESD.1329

faculty of engineering is being dominated by males, as such, they have an edge over their female counterparts, but the reverse is the case.

\section{Federal institutions of study and Underachievement}

The results show that Federal institutions of study have a significant influence with underachievement among Undergraduate Engineering students in South-South Federal Universities. This finding is an eye opener to the researcher, because it exposed her to the places were these students are being kept to learn. Some of them learn in a flooded classroom and of the federal universities have not received full accreditation, which could be a causative factor of the insignificant level.

\section{Department of study and Underachievement}

The findings of this study reveal that Departments of study do not have a significant influence with underachievement among Undergraduate Engineering students in South-South Federal Universities. The researcher is indifferent about the result because all the students learn together when learning the course Engineering Mathematics.

\section{Conclusion}

The major conclusion drawn from this study is that on a general basis federal institution of study and CGPA significantly influence underachievement, while gender and department of study do not influence underachievement.

\section{Recommendations}

On the basis of the result obtained, the following recommendations were made:

- Parents should ensure that they monitor the academic activities of their children.

- The government/non-governmental organizations have a major role to play in this issue of underachievement. They should ensure that they provide and supervise the utilization of funds in the federal institutions.

- Lecturers/teachers should devise a means for which they can use in identifying these underachievers so that special attention will be given to them.

- Guidance counsellors should organize seminars and workshops for underachievers to be educated on how to prevent underachievement.

\section{Limitations of the Study}

Despite the success of the present study, some factors limited the generalization of this result based on the federal institutions of study. These factors include:

- Network was a big issue, but it was managed with the change of sim card.

- Accommodation was another issue. The researcher had to sleep in the classroom

- Bad climatic conditions. The study was carried out during the raining season. 


\section{REFERENCES}

Akpan-Ita, N.E.I. (2008). Towards Utilizing New Digital Media Technologies for the promotion of Peace. Education in Nigeria. Ajote African Journal of Teacher Education. Vol.2 (1).

Amao-Kehinde, A. (2006). Gender sensitivity and Women Empowerment in Nigeria. Journal of Research in National Development Vol.7(1) June 2015

Donghyuck, L., Lim, H.J., Seon, H.Y., Hutchison, B., Mark, P. \& Hwang, M.H. (2014).

Academic underachievement and recovery: students' perspective on effective career interventions. http://doi.org/10.1002/j2161-0045.2014.00072.x.

Ebenuwa-Okoh, E.E. (2006). Gender and Age as moderators of the relationship between environmental variables and marital adjustment among married persons.

Department of Counselling Psychology Delta State University, Abraka,

Nigeria. E-mail:ebenuwaokoh@yahoo.com.

Hornby, A.S. (2010). Oxford advance learners' dictionary of contemporary English.

Oxford university press. Pp 483.

Logsdon, J. (2019). Fifty proven strategies for helping the underachieving students and improving schools in Norwegian. Htps://urfabook-n-cf>sitemap

McCoach, D.B. \&Siegle, D. (2003). Factors that differentiates the underachieving gifted students from the high achieving gifted students. Gifted child quart.47,144-154.

Nwankwo, O.C., (2013). A Practical Guide to Research Writing for Students of Research Enterprise (Rev. 5th ed.). Port Harcourt: University of Port Harcourt Press Ltd.

Okojie, J.A. (2010). System and strategies for funding Nigerian universities. http://www.nape.org.ng//index.php?option.com 